\title{
BACKFAT FATTY ACID PROFILE OF CROSSBRED PIGS FED A DIET SUPPLEMENTED WITH CONJUGATED LINOLEIC ACID OR SUNFLOWER OIL*
}

\author{
Przemysław Dariusz Wasilewski ${ }^{1}$, Jerzy Nowachowicz ${ }^{1}$, \\ Grażyna Michalska ${ }^{1}$, Tomasz Bucek ${ }^{1}$, Brendan Lynch ${ }^{2}$, \\ Anne Marie Mullen ${ }^{3}$
}

\author{
${ }^{1}$ Department of Animal Products Evaluation, Faculty of Animal Breeding and Biology, \\ University of Technology and Life Sciences in Bydgoszcz, Ks. Kordeckiego 20, 85-225 Bydgoszcz, \\ Poland \\ ${ }^{2}$ Moorepark Pig Production Centre, Teagasc, Fermoy, Co. Cork, Ireland \\ ${ }^{3}$ Ashtown Food Research Centre, Ashtown, Dublin, Ireland
}

\begin{abstract}
The aim of the study was to investigate the impact of feeding pigs with different levels of conjugated linoleic acid (CLA) or sunflower oil (SFO) on the backfat fatty acid profile. The subjects of research were 60 crossbred gilts divided into 6 groups, which were fed different levels of conjugated linoleic acid or sunflower oil $(0.5,1.0$ and $2.0 \%$, respectively). All fatteners were kept and fed under standardized conditions. Animals were slaughtered at $95 \mathrm{~kg}$ of body weight. Fatty acid profile was determined in samples of backfat from each animal using gas chromatography. The significance of differences between groups was verified by Duncan's test. In the present study, a beneficial effect of adding CLA was that it reduced saturated fatty acids and increased unsaturated fatty acids in the adipose tissue (backfat) of pigs as compared to fatteners receiving SFO. The amount of monounsaturated fatty acids in the backfat decreased with increasing amounts of CLA or SFO. Modifying the fatty acid profile of pig backfat through addition of CLA or SFO would be beneficial to the health of consumers because relatively large amounts of fat pork, including backfat, are added to the sausages.
\end{abstract}

Key words: conjugated linoleic acid, sunflower oil, crossbred pigs, backfat

One of the supplements which impacts on the improvement of health benefits of the pork meat is conjugated linoleic acid (CLA). In recent times many health properties of this substance have been discovered and described. These include stimulating

\footnotetext{
*The research was carried out within the confines of V European Union Framework (Marie Curie Fellowship) in Ashtown Food Research Centre (Dublin, Ireland).
} 
the immune system, anti-tumour activities, anti-atherosclerotic effects, regulating the blood glucose level, combating allergies and asthma (Kritchevsky, 2000; Bassaganya-Riera et al., 2002; Bawa, 2003). Many factors influence fatty acid profile of pig tissue, i.e. genetics (breed) and environment, including feeding (Raj et al., 2004) and also growth and development of experimental animals (Walkiewicz et al., 2001).

The gender of pigs may impact on the carcass traits and the fatty acid profile (Urbańczyk et al., 2002; Koczanowski et al., 2004). In the research of Koczanowski et al. (2004) it was observed that gilt backfat contained $1.20 \%$ less saturated and $1.59 \%$ more polyunsaturated fatty acids than barrow backfat.

In the experiment performed on rats, Azain et al. (2000) showed reduced amounts of monounsaturated fatty acids in the adipose tissue of animals supplemented with conjugated linoleic acid. Pieszka et al. (2004) observed that the decrease in triglycerides, total cholesterol and HDL cholesterol in blood plasma occurred with increasing dietary supplementation of CLA.

Weber et al. (2001), who estimated the effectiveness of dietary conjugated linoleic acid as a factor improving the growth of newborn pigs proved that addition of $0.6 \%$ CLA did not increase the growth rate of piglets. However, Pieszka et al. (2003) did not observe the impact of conjugated linoleic acid on the growth results of pigs.

The aim of this study was to investigate the effect of feeding diets with different levels of conjugated linoleic acid or sunflower oil on the backfat fatty acid profile of pigs.

\section{Material and methods}

The experiment covered 60 crossbred gilts, $\widehat{\sigma}$ Irish Landrace $\times q$ ( $\widehat{\sigma}$ Irish Landrace $\times q$ Irish Large White). The pigs were fattened from $40 \mathrm{~kg}$ to $95 \mathrm{~kg}$ of body weight in a pig-house of Teagasc in Moorepark (Ireland). The pigs were kept and fed under standardized conditions. The animals were maintained in $4.8 \mathrm{~m} \times 2.4 \mathrm{~m}$ boxes. Temperature ranged from 20 to $22^{\circ} \mathrm{C}$ and was computer-regulated (Steinen PCS 8200 Climate Controller).

The pigs were chosen at $40 \mathrm{~kg}$ of body weight and divided into 6 groups (10 individuals per group, 6 groups in total, each placed in a separate box). The diets were used as follows:

- Group 1. Diet with $0.5 \%$ of conjugated linoleic acid (CLA 0.5);

- Group 2. Diet with $1.0 \%$ of conjugated linoleic acid (CLA 1.0);

- Group 3. Diet with 2.0\% of conjugated linoleic acid (CLA 2.0);

- Group 4. Diet with $0.5 \%$ of sunflower oil (SFO 0.5);

- Group 5. Diet with 1.0\% of sunflower oil (SFO 1.0);

- Group 6. Diet with 2.0\% of sunflower oil (SFO 2.0).

The source of conjugated linoleic acid was Luta-CLA ${ }^{\circledR} 60$ preparation made by BASF containing at least $56 \%$ of CLA (C18:2) isomers, including at least $28 \%$ of c9 t11 and at least $28 \%$ of $\mathrm{t} 10 \mathrm{c} 12$. 
After the end of fattening period, animals were carefully transported to the Glanbia Meat Plant in Edenderry, Ireland. The animals were slaughtered after 24 hours of rest. Gas $\left(\mathrm{CO}_{2}\right)$ stunning was used.

After slaughter, backfat thickness was measured $6 \mathrm{~cm}$ from the back line at the height of the 3rd and 4th rib, using an opto-electronic probe (Hennessy Grading Probe). The meat content was calculated using the following formula:

$$
\text { Meat content, } \%=53.41-0.786 * X_{1}+0.266 * X_{2}
$$

where:

$X_{1}$ - backfat thickness;

$X_{2}$ - thickness of longissimus dorsi muscle.

Fatty acid profile was determined in the samples of longissimus dorsi muscle from each animal. Gas chromathography was used, i.e. Varian 3400 Gas Chromatograph equipped with SGE BPX-70 column, $120 \mathrm{~m}$ length, $0.25 \mathrm{~mm}$ diameter (Phenomenex).

The results were analysed statistically, and the mean $(\bar{x})$ and standard deviation (s) were calculated. The significance of differences between tested groups was verified by Duncan's test. A computer program Statistica 8.0 PL (2008) was used.

\section{Results}

Table 1 presents the backfat thickness and total amount of saturated and unsaturated (mono and polyunsaturated) fatty acids and their ratio in the backfat of pigs fed diets with added conjugated linoleic acid or sunflower oil.

The backfat thickness of tested pigs was small and fairly uniform. There were no statistically significant differences between the groups in this regard. However, a tendency can be observed towards reduced backfat thickness in the groups receiving the highest $(2 \%)$ or the lowest $(0.5 \%)$ dose of conjugated linoleic acid or sunflower oil compared to the group of pigs fed the diet with the addition of $1 \%$ CLA or sunflower oil, where the backfat thickness was the highest.

A lower concentration of saturated fatty acids (SFA) was observed in the backfat of pigs fed conjugated linoleic acid (from $41.89 \%$ to $44.27 \%$ ) as compared to the individuals supplemented with sunflower oil (from $46.52 \%$ to $49.12 \%$ ). This was confirmed with statistical differences $(\mathrm{P} \leq 0.01)$. It should be noted that the lowest amount of saturated fatty acids in the backfat was in the groups of animals receiving the highest supplement $(2 \%)$ of conjugated linoleic acid or sunflower oil.

An inverse trend was observed for unsaturated fatty acids (UFA). The animals receiving conjugated linoleic acid had a significantly higher $(\mathrm{P} \leq 0.01)$ amount of these acids (from 55.73 to $58.11 \%$ ) as compared to the individuals supplemented with sunflower oil (from 50.88 to $53.48 \%$ ). 


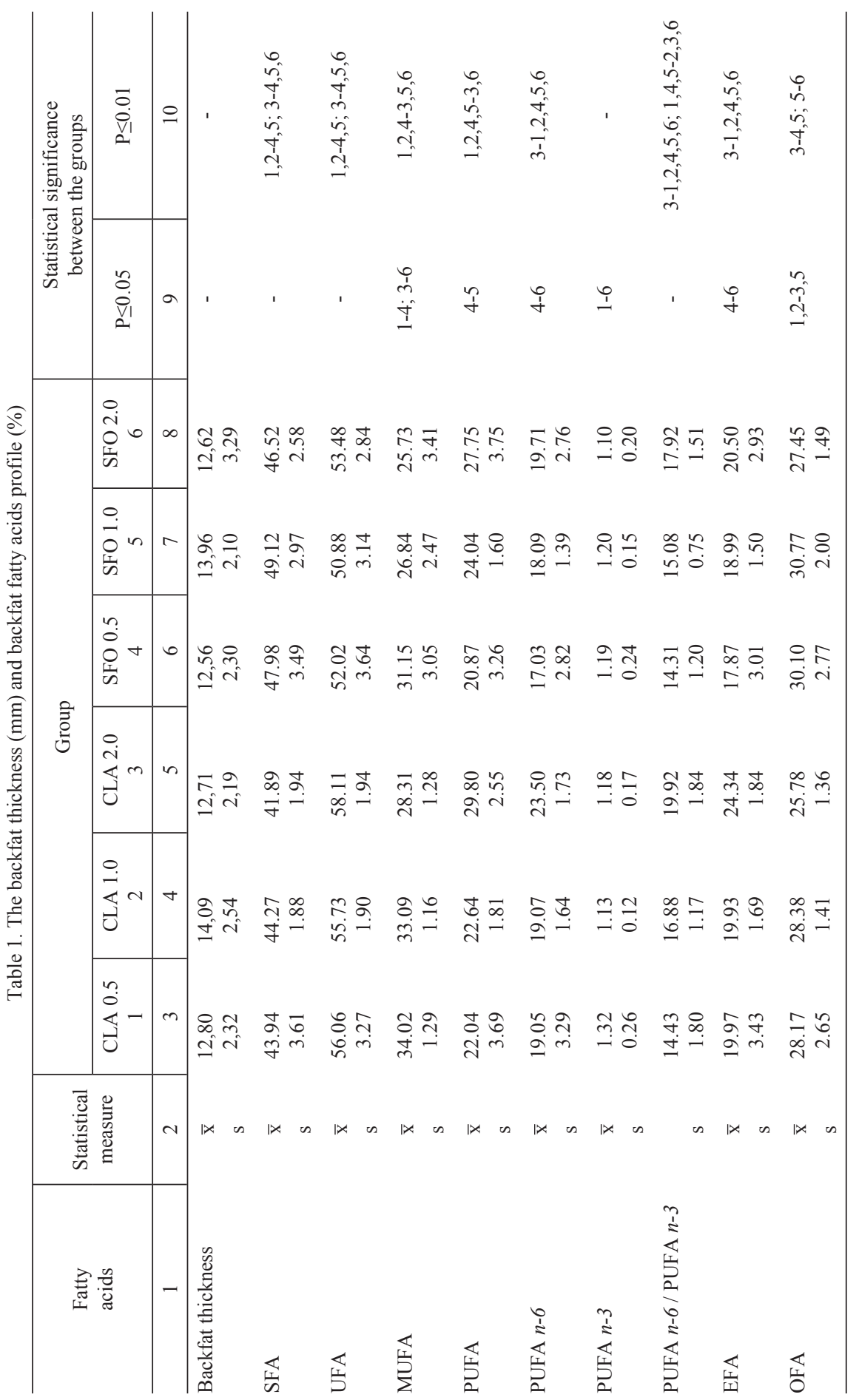




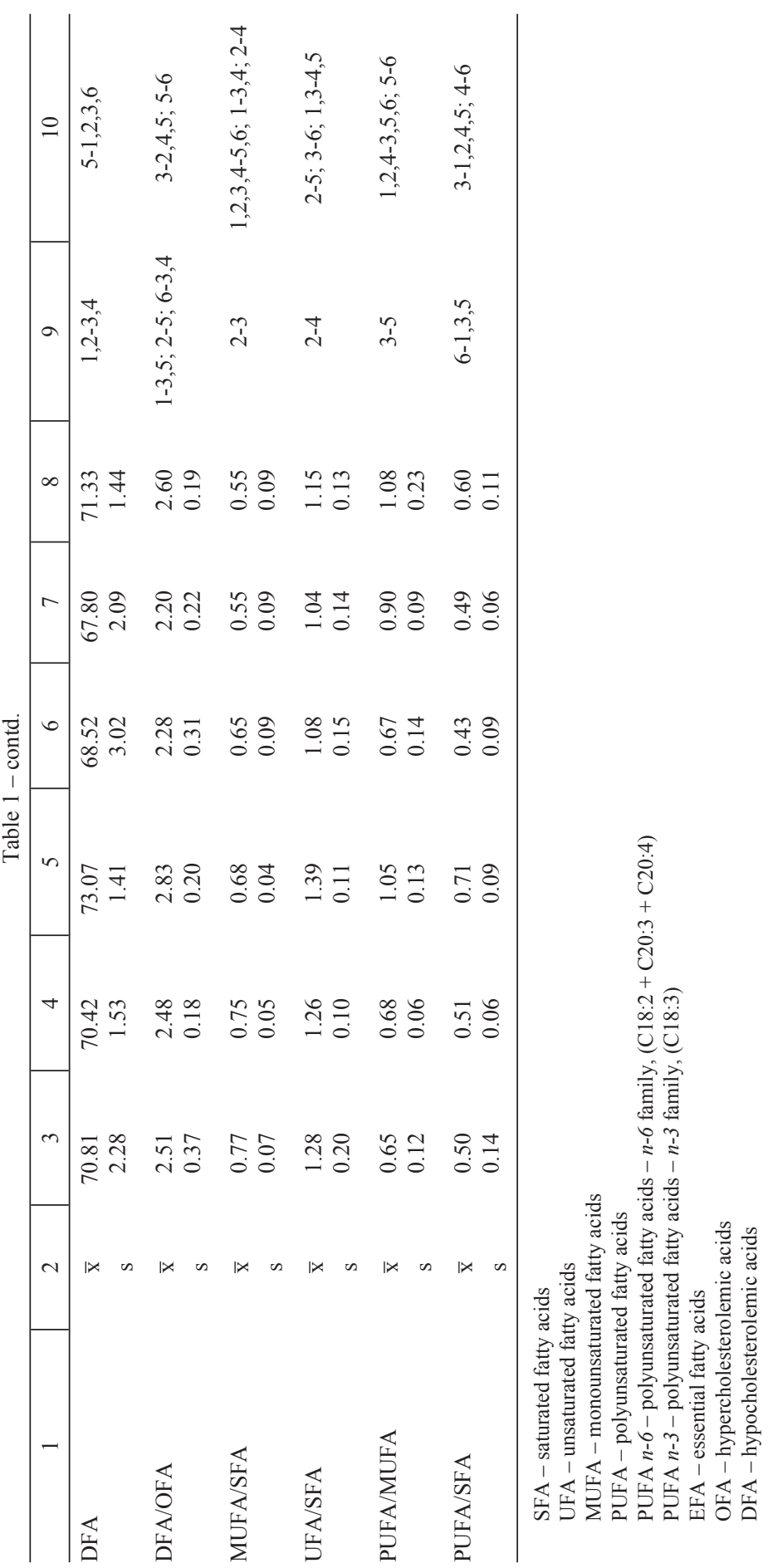


The highest concentration $(34.02 \%)$ of monounsaturated fatty acids (MUFA) was in group 1 and the lowest $(25.73 \%)$ in group 6 . Highly significant statistical differences were observed between groups 1, 2, 4 and 3, 5, 6, and significant differences between groups 1 and 4 and also between groups 3 and 6 . In the tested groups of animals (supplemented with conjugated linoleic acid or sunflower oil) there can be seen a trend towards a decrease in monounsaturated fatty acids with increasing concentration of CLA or SFO in the diet.

The lowest concentration $(20.87 \%)$ of polyunsaturated fatty acids (PUFA) occurred in group 4 and the highest $(29.80 \%)$ in group 3 . Highly significant statistical differences were proved between groups 1, 2, 4, 5 and 3, 6. A statistically significant difference was confirmed between groups 4 and 5 . The amount of polyunsaturated fatty acids in the backfat of animals fed with CLA or SFO tended to increase with increasing proportion of the tested substance in the diet.

The highest concentration of polyunsaturated fatty acids of the $n-6$ family ( $n-6$ PUFA) was in group 3, namely in pigs supplemented with $2 \%$ conjugated linoleic acid $(23.50 \%)$, and the lowest in group 4 , in animals supplemented with $0.5 \%$ sunflower oil (17.03\%). Highly significant differences were proved between group 3 and all the remaining groups, and a statistically significant difference was confirmed between groups 4 and 6 .

The polyunsaturated fatty acids of the $n-3$ family ( $n-3$ PUFA) were the highest $(1.32 \%)$ in the group of fatteners supplemented with $0.5 \%$ conjugated linoleic acid. The lowest concentration $(1.10 \%)$ was observed in the group supplemented with $2 \%$ sunflower oil. Between these groups a statistically significant difference was confirmed.

The lowest ratio of $n-6$ to $n$ - 3 PUFA was found in animals from the group receiving sunflower oil (0.5\%) as a feed supplement. Between groups 3 and 1, 2, 4, 5, 6 and also between groups 1, 4, 5 and 2, 3, 6 highly significant statistical differences were found. An unfavourable trend towards higher $n-6$ to $n-3$ PUFA ratio was seen with the increasing dietary level of conjugated linoleic acid or sunflower oil.

The highest concentration $(24.34 \%)$ of essential fatty acids (EFA) was observed in group 3 and the lowest $(17.87 \%)$ in group 4 . Highly significant differences were proved between group 3 and all the remaining groups, and a statistically significant difference was confirmed between groups 4 and 6 .

The highest amount (30.77\%) of hypercholesterolemic acids (OFA) was in the group of animals receiving $1 \%$ sunflower oil and the lowest $(25.78 \%)$ in the group of pigs supplemented with $2 \%$ conjugated linoleic acid. Highly significant statistical differences were confirmed between groups 3 and 4, 5 and also 5 and 6 , and statistically significant differences were proved between groups 1,2 and 3,5 .

The highest concentration (73.07\%) of hypocholesterolemic acids (DFA) was in the group of animals supplemented with $2 \%$ conjugated linoleic acid. The lowest $(67.80 \%)$ amount of DFA was observed in the groups of pigs fed a diet supplemented with $1 \%$ sunflower oil, and highly significant statistical differences were confirmed between this group (5) and groups 1, 2, 3, 6. Between groups 1, 2 and 3, 4, statistically significant differences were found. 
DFA to OFA ratio was the lowest (2.20) in group 5 and the highest (2.83) in group 3. Between groups 3 and 2, 4, 5 and also between groups 5 and 6 highly significant statistical differences were proved. Between groups 1 and 3, 5, groups 2 and 5 and 6 , and groups 3 and 4, the differences were statistically significant.

In the case of MUFA and SFA, the lowest ratio (0.55) was determined in groups 5 and 6, and the highest (0.77) in group 1. Between groups 1, 2, 3, 4 and 5, 6; 1 and 3, 4; and also 2 and 4 highly significant statistical differences were observed. A statistically significant difference was proved between groups 2 and 3 .

The lowest UFA to SFA ratio (1.04) was in group 5 and the highest (1.39) in group 3. There were highly significant statistical differences between groups 2 and 5; 3 and 6; and also 1, 3 and 4, 5, and a statistically significant difference between groups 2 and 4 .

The lowest PUFA to MUFA ratio occurred in groups 1,4 and $2(0.65 ; 0.67 ; 0.68)$, and the highest $(1.08 ; 1.05 ; 0.90)$ in groups 6,3 and 5 , respectively. The differences between these groups were confirmed to be highly significant. Moreover, a statistically significant difference occurred between groups 3 and 5 .

The lowest PUFA to SFA ratio (0.43) was in group 4 and the highest $(0.71)$ in group 3. Highly significant differences were observed between groups 3 and 1, 2, 4, 5 and also between groups 4 and 6 , and statistically significant differences $(\mathrm{P} \leq 0.05)$ were found between groups 6 and $1,3,5$.

\section{Discussion}

The present study showed that the addition of conjugated linoleic acid to the diet was favourable in that it reduced saturated fatty acids and increased unsaturated fatty acids in the adipose tissue (backfat) of pigs as compared to the fatteners receiving sunflower oil. The amount of monounsaturated fatty acids in the backfat decreased and that of polyunsaturated fatty acids increased with increasing amounts of conjugated linoleic acid or sunflower oil in the diet.

High amounts of SFA (C12:0, C14:0 and C16:0) may cause an increase in total cholesterol in blood serum. C16:0 acid also has atherogenic activity (Bolton-Smith et al., 1991). However, C18:1 decreases the risk of heart and cardiovascular diseases (Hoffman et al., 2007). The health-promoting and nutritional value of meat mainly depends on the content of polyunsaturated fatty acids (C18:2 and C18:3) (Xiccato and Trocino, 2003). It is recommended to reduce $n 6 / n 3$ PUFA to below 4 while determining the content of linoleic acid (C18:3n3) and arachidonic acid (C20:4n6). It is also important that the ratio of polyunsaturated fatty acids to saturated fatty acids exceeded 0.4 (Wood et al., 2003), which was also observed in the present study.

In our previous research (Wasilewski et al., 2011) it was observed that the addition of conjugated linoleic acid or sunflower oil did not impact on the variation of saturated or unsaturated fatty acids in the longissimus dorsi muscle. It is worth adding that the meat content, and thus the carcass meat percentage of pigs from the groups supplemented with $0.5,1.0$ and 2.0\% CLA and SFO was high at 57.94; 57.18; 58.57 
and 58.63; 57.35; 57.88\%, respectively (Wasilewski et al., 2006). Although there were no statistically significant differences in the analysed trait, it should be noted that the lowest meat content in both groups was characteristic of animals receiving conjugated linoleic acid or sunflower oil at 1\%. This corresponds with the measurements of backfat thickness, because individuals from these groups were characterized by the thickest layer of subcutaneous fat (Table 1). It should be noted that the tested fatteners were slaughtered at a fairly low body weight of approximately $95 \mathrm{~kg}$, which resulted in their backfat being thin and having high meat content.

Jiang et al. (2010) reported that the addition of CLA to the feed of pigs increased the content of lean meat (from 3.5 to $4.7 \%$ ) and intramuscular fat and reduced backfat thickness (from 12.9 to $16.6 \%$ ).

It should be remembered that adipose tissue, which has a high proportion of unsaturated fatty acids, is greasy and soft (Larsen et al., 2009; White et al., 2009). This is not always a desirable trait in many technological processes.

According to Migdał et al. (1999), the ratio of unsaturated to saturated fatty acids and the amount of essential fatty acids in the loin and backfat fat depend on pig feeding, especially on the dietary proportion of feeds with high amounts of linoleic and linolenic acids.

Thiel-Cooper et al. (2001) observed a linear increase of conjugated linoleic acid in the subcutaneous fat of pigs $(\mathrm{P} \leq 0.001)$. Similarly, Ostrowska et al. (2003) and Tischendorf et al. (2002) proved that pigs receiving CLA had higher CLA levels in adipose tissue. Bee (2000) also confirmed the impact of conjugated linoleic acid on the composition of backfat fatty acids.

Different results were presented by Stangl et al. (1999). Unlike other experiments, they did not observe dietary CLA supplementation to alter the fatty acid profile.

Pieszka et al. (2004) observed that pigs from the groups supplemented with conjugated linoleic acid had a higher proportion of saturated fatty acids and a lower proportion of monounsaturated fatty acids in tissues. Also Müller et al. (2003) proved higher levels of the polyunsaturated fatty acids in the adipose tissue of pigs.

Grześkowiak et al. (2002) observed a significant impact of flax seed supplementation on increasing the amount of unsaturated fatty acids. As compared to the control group, the backfat of animals supplemented with flax contained $5.39 \%$ more polyunsaturated fatty acids. Moreover, the $n-6$ to $n-3$ PUFA ratio in the backfat of fatteners from the tested group decreased to 2.78 compared to 7.05 in the control group.

It should be noticed that the fatty acid profile samples from the dorsal and lumbar part of backfat and also from their external and internal part show differences. The internal part of backfat has more saturated fatty acids than the external part (Migda1 et al., 2001).

In summary, a beneficial effect of adding conjugated linoleic acid was that it reduced saturated fatty acids and increased unsaturated fatty acids in the adipose tissue (backfat) of pigs as compared to fatteners receiving sunflower oil. The amount of monounsaturated fatty acids in the backfat decreased with increasing amounts of conjugated linoleic acid or sunflower oil. Modifying the fatty acid profile of pig backfat through addition of CLA or sunflower oil would be beneficial to the health 
of consumers because relatively large amounts of fat pork, including backfat, are added to the sausages.

\section{References}

A za in M.J., Hausman D.B., S is k M.B., Flatt W.P., Je we 11 D.E. (2000). Dietary conjugated linoleic acid reduces rat adipose tissue cell size rather than cell number. J. Nutr., 130 (6): $1548-1554$

B a s s a ganya-Riera J., H on tecillas R., B e itz D.C. (2002). Colonic anti-inflammatory mechanisms of conjugated linoleic acid. Clinic. Nutr., 21 (6): 451-459.

B a w a S. (2003). An update on beneficial role of conjugated linoleic acid (CLA) in modulating human health: mechanisms of action. Pol. J. Food Nutr. Sci., 12/53 (3): 3-14.

B e e G. (2000). Dietary conjugated linoleic acids alter adipose tissue and milk lipids of pregnant and lactating sows. J. Nutr., 130 (9): 2292-2298.

B olton-Smith C., Woodward M., S mith W.C.S., Tun stall-Ped oe H. (1991). Dietary and non dietary predictors of serum total HDL cholesterol in men and women: results from the Scottish Heart Health Study. Int. J. Epidemiol., 20, 95-104.

Grześk owiak E., B orzuta K., Tratwa 1 Z. (2002). Effect of feeding pigs with concentrates supplemented with linseeds on fatty acid profile in backfat. Ann. Anim. Sci. Suppl., 2: 289-292.

H o ff ma n L.C., Krouc a m p M., M a n ley M. (2007). Meat quality characteristic of springbok (Antidorcas marsupialis). 3: Fatty acid composition as influenced by age, gender and production region. Meat Sci., 76: 768-773.

Ji ang Z.Y., Zhong W.J, Zheng C.T., Lin Y.C., Y ang L., J i ang S. Q. (2010). Conjugated linoleic acid differentially regulates fat deposition in backfat and longissimus muscle of finishing pigs. J. Anim. Sci., 88: 1694-1705.

Koczanowski J., Migdał W., Orzechowska B. (2004). The effect of backfat thickness and fattener's sex on fatty acid composition of backfat (in Polish). Pr. Mat. Zoot., Zesz. Spec., 15: $238-239$.

Kritchevsky D. (2000). Antimutagenic and some other effects of conjugated linoleic acid. Brit. J. Nutr., 83 (5): 459-465.

L a r s e n S.T., W i e g a d B.R., P a r r i s h F.C., Jr., S w a n J.E., S p a r k s J.C. (2009). Dietary conjugated linoleic acid changes belly and bacon quality from pigs fed varied lipid sources. J. Anim. Sci., 87: 285-295.

Migdał W., B orowiec F., K o c zanows ki J. (2001). The fatty acids of inner and outer backfat of crossbred fatteners (in Polish). Zesz. Nauk. AR we Wrocławiu, Konf. XXXI, nr 405: 175-180.

Migdał W., Koczanowski J., B orowiec F., Furgał K., B arteczko J., Klocek Cz., Tuz R., Gardzińska A., Kurek M. (1999). Effect of feeding on the fatty acid compositon of loin and backfat in fatteners (in Polish). Zesz. Nauk. AR w Krakowie, Sesja Nauk. Genetyczne i środowiskowe problemy w hodowli trzody chlewnej, Kraków, 28 września, Zesz. 67: 199-207.

Müller S., Reichardt W., Hartung H., Eckert B. (2003). Analyse der Fettsäurenzusammensetzung des Rohfettes von Prüffutter für Schweine (Kurzmitteilung). Arch. Tierz., Dummerstorf, 46: 273-276.

Ostrowska E., Cross R.F., Muralitharan M., Bauman D.E., Dunshea F.R. (2003). Dietary conjugated linoleic acid differentially alters fatty acid composition and increases conjugated linoleic acid content in porcine adipose tissue. Brit. J. Nutr., 90 (5): 915-928.

Pieszka M., Paściak P., B arowicz T., Wojtysiak D., Pustkowiak H., Migdał W. (2004). Effect of conjugated linoleic acid (CLA) addition to the diet on composition of fatty acids and lipids in pig blood. Ann. Anim. Sci., Suppl. 2: 165-170.

P ieszka M., Paściak P., Wojtys iak D., B arowicz T., Migdał W. (2003). The impact of different CLA level in fodder on the results of growth performance of PLW pigs (in Polish). Konf. Nauk.: Prace genetyczno-hodowlane nad świniami ras rodzimych, Poznań, 18-19 listopad 2003 . 
Raj S., Skiba G., Weremko D., Fandrejewski H., Migdał W., B orowiec F. (2004). Fatty acid composition of longissimus dorsi muscle in pigs as affected by breed and body weight (in Polish). Pr. Mat. Zoot., Zesz. Spec., 15: 245-246.

S t a n g l G.I., Mue ll e r H., K ir ch ge s s n e r M. (1999). Conjugated linoleic acid effects on circulating hormones, metabolites and lipoproteins, and its proportion in fasting serum and erythrocyte membranes of swine. Europ. J. Nutr., 38 (6): 271-277.

Statistica 8.0 PL (2008). StatSoft Polska

Th i e l- C o o p e r R.L., P a r r is h F.C., S p ark s J.C., W i e g a n d B.R., E w a n R.C. (2001). Conjugated linoleic acid changes swine performance and carcass composition. J. Anim. Sci., 79 (7): $1821-1828$.

T is chendorf F., S chone F., K irchhe im U., Jahre is G. (2002). Influence of a conjugated linoleic acid mixture on growth, organ weights, carcass traits and meat quality in growing pigs. J. Anim. Physiol. Anim. Nutr., 86 (3-4): 117-128.

Urbańczyk J., Św iątki ew ic z M., Hanczakowska E., S i e mińska M. (2002). Effect of various protein feeds on carcass traits, meat quality and fatty acid composition of backfat of gilts and barrows. Ann. Anim. Sci., Suppl., 2: 277-281.

W a lki ew ic z A., W i elbo E., Matyka S., B abicz M., D zi ubak A., Tochman L. (2001). Effect of pig somatic development on a cholesterol content and fatty acid composition in pork (in Polish). Zesz. Nauk. AR we Wrocławiu, Konf. XXXI, 405: 255-261.

Wasilewski P.D., Nowachowicz J., Michalska G., Bucek T., Lynch B., Mull e n A.M. (2011). Fatty acid profile of Longissimus dorsi muscle of crossbred pigs fed with addition of conjugated linoleic acid or sunflower oil. Arch. Tierz., Dummerstorf, 54, 1: 61-68.

W asilewski P.D., Nowachowicz J., Michalska G., Lynch B., Mullen A.M. (2006). The impact of addition of conjugated linoleic acid on chemical composition of Longissimus dorsi muscle and meat content of pigs. Anim. Sci., 1: 190-191.

W e b e r T.E., S c h in c kel A.P., H o u s e k n e ch t K.L., R i che r t B.T. (2001). Evaluation of conjugated linoleic acid and dietary antibiotics as growth promotants in weanling pigs. J. Anim. Sci., 79 (10): 2542-2549.

White H.M., Richert B.T., R a d c 1 iffe J.S., S ch inckel A.P., B urges s J.R., K o se r S.L., D o n k in S.S., L a t o u r M.A. (2009). Feeding conjugated linoleic acid partially recovers carcass quality in pigs fed dried corn distillers grains with solubles. J. Anim. Sci., 87:157-166.

W o od J.D., Richardson R.I., Nute G.R, F isher A.V, C a mpo M.M., K a s a pidou E., S h e ard P.R., En s e r M. (2003). Effects of fatty acids on meat quality: a review. Meat Sci., 66: 21-32.

X i c c a t o G., T r o c in o A. (2003). Role of dietary lipid on digestive physiology, immune system and growth in rabbits. Cost 848, Agric. Biotechnol., pp. 239-244.

Accepted for printing 9 II 2012

PRZEMYSŁAW DARIUSZ WASILEWSKI, JERZY NOWACHOWICZ, GRAŻYNA MICHALSKA, TOMASZ BUCEK, BRENDAN LYNCH, ANNE MARIE MULLEN

\section{Profil kwasów thuszczowych w słoninie świń mieszańców żywionych paszą z dodatkiem sprzężonego kwasu linolowego lub oleju słonecznikowego}

\section{STRESZCZENIE}

Celem pracy było zbadanie wpływu żywienia świń paszą z dodatkiem różnego poziomu sprzężonego kwasu linolowego lub oleju słonecznikowego na profil kwasów tłuszczowych w słoninie. Przedmiotem badań było 60 loszek mieszańców podzielonych na 6 grup, żywionych paszą z dodatkiem sprzężonego kwasu linolowego (CLA) lub oleju słonecznikowego (SFO) w ilościach odpowiednio: 0,$5 ; 1,0$ i 2,0\%. Tuczniki były utrzymywane i żywione w ujednoliconych warunkach. 
Zwierzęta zostały ubite przy masie ciała $95 \mathrm{~kg}$. Profil kwasów tłuszczowych został oznaczony na próbkach słoniny pochodzących od każdego osobnika przy użyciu chromatografii gazowej. Istotność różnic pomiędzy grupami została zweryfikowana testem Duncana. Korzystnym następstwem dodawania do paszy sprzężonego kwasu linolowego było obniżenie zawartości nasyconych oraz wzrost udziału nienasyconych kwasów tłuszczowych w tkance tłuszczowej świń (słoninie) w stosunku do tuczników otrzymujących olej słonecznikowy. Zawartość jednonienasyconych kwasów tłuszczowych w słoninie malała, a wielonienasyconych rosła w miarę zwiększania koncentracji sprzężonego kwasu linolowego lub oleju słonecznikowego w paszy. Modyfikowanie profilu kwasów tłuszczowych w słoninie świń poprzez dodatek do paszy CLA lub oleju słonecznikowego byłoby korzystne dla zdrowia konsumentów gdyż stosunkowo dużo tłuszczu wieprzowego, w tym słoniny, dodawane jest do wędlin. 